\title{
AKVAKULTÚRA FEJLESZTÉS LAOSZBAN MAGYAR RÉSZVÉTELLEL
}

\author{
Bozánné Békefi Emese - Gyalog Gergő - Váradi László
}

\begin{abstract}
Absztrakt: A világ növekvő népességének élelmiszerellátása a jövő egyik nagy kihívása tekintettel az erőforrások szükösségére és a globális klímaváltozásra. A hal és más vízi élelmiszerek kiemelkedő szerepet játszhatnak az élelmiszerellátásban különös tekintettel arra, hogy az akvakultúra ökológiai lábnyoma lényegesen kisebb, mint más élelmiszertermelő rendszereké. Bár a tengeri akvakultúra termelése növekvő tendenciát mutat, a világ akvakultúra termelésében meghatározó marad az édesvízi élölények termelése, különösen a fejlődő országokban. A világ szegényebb országai élelmiszertermelésének a jövőbeni kihívásokkal szembeni ellenállóképessége igen gyenge, ezért számos nemzetközi projekt próbál a helyzeten javítani. A világ legfejletlenebb országai közé tartozik Laosz, ahol az akvakultúrának fontos szerepe van a halellátásban és a foglalkoztatásban. Laoszban több nemzetközi projekt segíti az agrárgazdaság és az élelmiszerellátás fejlesztését, azonban Magyarország az egyik legnagyobb donor e területen, tekintettel a két ország közötti hagyományos agrár kapcsolatokra és a stratégiai együttmüködésre. Laoszban a gazdag vízi erőforrások jó lehetőséget biztosítanak a halászat és az akvakultúra fejlesztésére, azonban a lehetőségek kihasználását számos tényező nehezíti. Olyanok, mint például a minőségi ivadék- és takarmányellátás hiánya, a fejletlen infrastruktúra és intézményrendszer, a finanszírozási problémák, illetve a képzett munkaerő hiánya. A magyar kormány által Laosz számára biztosított kötött segélyhitelek kiemelt célja az élelmiszerbiztonság és az élelmiszerellátás biztonságának javítása. E programokban a hal értéklánc fejlesztésének fontos szerepe van, amely nemzetközileg is példaértékü. A magyar projektek segítik azt is, hogy magyar intézmények, illetve kis- és közepes vállalkozások erösíthetik jelenlétüket Délkelet Ázsiában, amelyik a világ egy gazdaságilag dinamikusan fejlődő régiója.
\end{abstract}

Abstract: Food security for the world's growing population is one of the biggest challenges of the future due to resource constraints and global climate change. Fish and other aquatic foods can play a prominent role in the food supply, especially as the ecological footprint of aquaculture is smaller than that of other food production systems. Although the production of marine aquaculture shows an increasing trend, freshwater aquaculture remains dominant in world aquaculture production, especially in developing countries. The resilience of developing countries to the future challenges in food production is very low, so many international projects are trying to improve the situation. Laos is one of the least developed countries of the world, where aquaculture plays an important role in fish supply and employment. In Laos, several international projects are addressed to develop the agricultural economy and food supply, but Hungary is one of the largest donors in this field, given the traditional agricultural relations and strategic cooperation between the two countries. Although the abundance of aquatic resources provides a good opportunity for the development of fisheries and aquaculture in Laos, the growth of the fishery sector is hampered by several factors. These include the lack of good quality stocking material and fish feed, the underdeveloped infrastructure and institutional system, funding problems and weak human resources. The main purpose of the tied aid loans provided by the Hungarian government to Laos is to improve food safety and food security. The development of the fish value chain plays an important role in these programs, which can be considered as a good example even on international level. Hungarian projects also help Hungarian institutions and small and medium-sized enterprises to strengthen their presence in Southeast Asia, that is a region of the world where economy is developing in a dynamic way.

Kulcsszavak: akvakultúra, élelmiszerbiztonság, az élelmiszerellátás biztonsága, hal értéklánc

Keywords: aquaculture, food safety, food security, fish value chain 


\section{Bevezetés}

A halak, illetve a vízi élelmiszerek (beleértve a kagylókat, rákokat és egyéb emberi fogyasztásra alkalmas vízi növényeket és vízi állatokat) növekvő szerepet játszanak az élelmiszerellátásban szerte a világon, hiszen az 1961 és 2017 közötti időszakot tekintve a halászati és akvakultúra termelés bővülésének üteme (évente 3,1\%) felülmúlja a népesség növekedésének ütemét (évente 1,6\%) (FAO, 2020). A vízi élelmiszerek egyre nagyobb hányada származik termelésből, vagyis akvakultúrából (FAO, 2020), az elmúlt években (2013 óta) pedig globálisan az akvakultúra termelés (vízi növényekkel együtt) meghaladja a természetes vízi (elsősorban tengeri) fogásokat. Az akvakultúra egyben a legdinamikusabban fejlődő élelmiszertermelő ágazat a növekedési ütemet tekintve. A világ akvakultúra termelése, a vízi növényeket nem számolva 85,3 millió tonna volt 2019-ben (FAO, 2021a). Szükség van azonban a haltermelés további növelésére, ami becslések szerint a 2050-re el kell, hogy érje a 152 millió tonnát (Naylor et al., 2021), hogy kielégítse az addigra kb. 10 milliárd före növekvő népesség igényét. Az akvakultúra fejlödése az élelmezésben betöltött szerepen túl a klímaváltozás, valamint egyéb környezeti problémák mitigálása miatt is kívánatos, hiszen a termelés fajlagos ökológiai lábnyoma kisebb, mint más egyéb állattenyésztő ágazatoké (Waite et al., 2014). Jelentős eröfeszítések történnek világszerte, hogy innovációval növelni lehessen az akvakultúra fenntartható termelését és ellenállóképességét, hiszen az akvakultúra termelési technológiák jelentős része kitett az időjárás hatásainak. Különösen nagy kihívás az egészséges élelmiszerek iránti igény kielégítése a fejlődő országokban, ahol a kihívások leküzdése nemzetközi összefogást igényel. Az ENSZ, illetve annak Élelmezésügyi és Mezőgazdasági Szervezete (FAO) különös figyelmet fordít a fejlődő országok élelmiszerellátásnak a javítására, amely érdekében stratégiák és programok készültek. Ilyenek például az ENSZ Millenniumi Fejlesztési Célok (KSH, 2021), illetve konkrétan az akvakultúra fejlesztésre vonatkozóan a 2021 novemberében megtartott Akvakultúra Világkonferencia által kiadott Sanghaji Nyilatkozat (GCA2020; 2021). A világ legszegényebb országai közé tartozik Laosz, ahol az akvakultúrának fontos szerepe van a halellátásban és a foglalkoztatásban. Laoszban a gazdag vízi erőforrások, elsősorban a Mekong folyó és mellékvizei jó lehetőséget biztosítanak a halászat és az akvakultúra fejlesztésére, azonban a lehetőségek kihasználását számos tényező nehezíti. Ilyenek például a minőségi ivadék- és takarmányellátás hiánya, a fejletlen infrastruktúra és intézményrendszer, a finanszírozási problémák, illetve a képzett munkaerő hiánya. A halászat és az akvakultúra fejlesztése a laoszi élelmiszerellátás- és foglalkoztatás javításának egyik olyan kulcsterülete, amely régi eleme a Magyarország és Laosz közötti hagyományos agrárkapcsolatoknak. Így Magyarország aktív részvétele a laoszi halellátás fejlesztésében hatékonyan járulhat hozzá az ország gazdasági és társadalmi fejlődéséhez, különösen úgy, hogy a halellátás fejlesztési program olyan programokkal kapcsolódik össze, mint a takarmányellátás-, a feldolgozás-, a marketing-; élelmiszerlánc biztonság-; és a humán erőforrások fejlesztése. 


\section{Az akvakultúra helyzete és fejlesztési lehetőségei Laoszban}

\subsection{Vízi erőforrások, halfajok, technológiák}

A Mekong mentén, Délkelet-Ázsia középső területén fekszik a Laoszi PDR egy szárazfölddel nem rendelkező etnikailag sokszínü ország. Lakossága 2020-ban kb. 7,2 millió fó volt, azonban a felmérések azt igazolják, hogy Laoszban tapasztalható az egyik leggyorsabban növekvő urbanizációs ráta Délkelet-Ázsián belül, ahol a lakosság várhatóan eléri 2030-ra a 8,2 millió, 2045-re pedig a 9,4 millió föt (UN, 2020). Laoszban az agrárszektor (növénytermelés, állattenyésztés, halászat és erdőgazdálkodás) a nemzetgazdaság egyik fő pillére. A foglalkoztatottak mintegy 71\%-a az agrár szektorban dolgozik, elsősorban kisméretü családi gazdaságokban. A GDP 48\%-a (Kína után a második leggyorsabb ütemben növekvő GDP a régióban) a mezőgazdaságból, illetve a természeti erőforrások hasznosításából származik. Laosz számára tehát stratégiai fontosságú a természeti erőforrások fenntartható hasznosítása. Laoszban bőségesen állnak rendelkezésre vízi erőforrások halászati és akvakultúra hasznosításra, az egy före jutó évente megújuló vízkészlet mintegy 48.000 köbméter, amely lényegesen magasabb a környékbeli országokra kalkulált mutatónál (FAO, 2021b). Összehasonlításképpen, az igen jelentős akvakultúra termeléssel rendelkező Kínában, Vietnamban, valamint Thaiföldön ez a mutató rendre 2000, 9300, valamint 6300 köbméter/fö, amely jól mutatja a laoszi édesvízkészlet adta lehetőségeket. Mindezzel együtt a növekvő népesség és az urbanizáció, valamint a vízfolyások energetikai hasznosítása, továbbá a mezőgazdaság intenzifikálása és a bányászat miatt a vízgazdálkodás egy igen komplex kérdés (McCartney-Brunner, 2020). A vízgazdálkodáson belül dinamikus kölcsönkapcsolat van a vízellátás, az élelmiszertermelés és az energiatermelés között, ami nem minden esetben kedvező a halászati hasznosításra vonatkozóan.

A halászatnak fontos szerepe van a foglalkoztatásban és a lakosság fehérje ellátásában. A hal elsősorban a Mekong folyóból, illetve mellékvizeiből származik. Laosz vizeiben mintegy 590 halfaj él, melynek 94\%-a öshonos, azonban gazdasági jelentőséggel 17 faj bír, amelynek szerepe van az akvakultúrában, különösen a kis családi farmok gazdálkodásában, illetve a halellátásban. Az akvakultúra termelés növekvő fontosságú, amely 113000 tonna volt 2019-ben (FAO, 2021a). Az akvakultúra termelés alakulását a 2009 és 2019 közötti időszakban az 1. ábra mutatja. Bár az adatszolgáltatás pontossága megkérdőjelezhető, az akvakultúra termelés növekedése egyértelmű. Az akvakultúra fajonkénti összetételét mutatja a 2. ábra 2019-ben, amely szerint a termelésben meghatározó faj (36 000 tonna, az összes termelés 32\%-a) a Nílusi tilápia (Oreochromis niloticus), amelyet elsősorban nagyobb folyókban elhelyezett ketrecekben intenzíven nevelnek. A három kínai növényevő faj (amur (Ctenopharyngodon idella), fehér busa (Hypophthalmichthys molitrix), és a pettyes busa (Hypophthalmichthys nobilis)) összesen $22 \%$-ot, a három indiai pontyféle $17 \%$-ot tesz ki az összes akvakultúra termelésböl. A ponty (Cyprinus carpio) részesedése az összes termelésből 6,2\%-ot tett ki 2019-ben. 


\section{1. ábra: A laoszi akvakulltúra termelés 2000 és 2019 között}

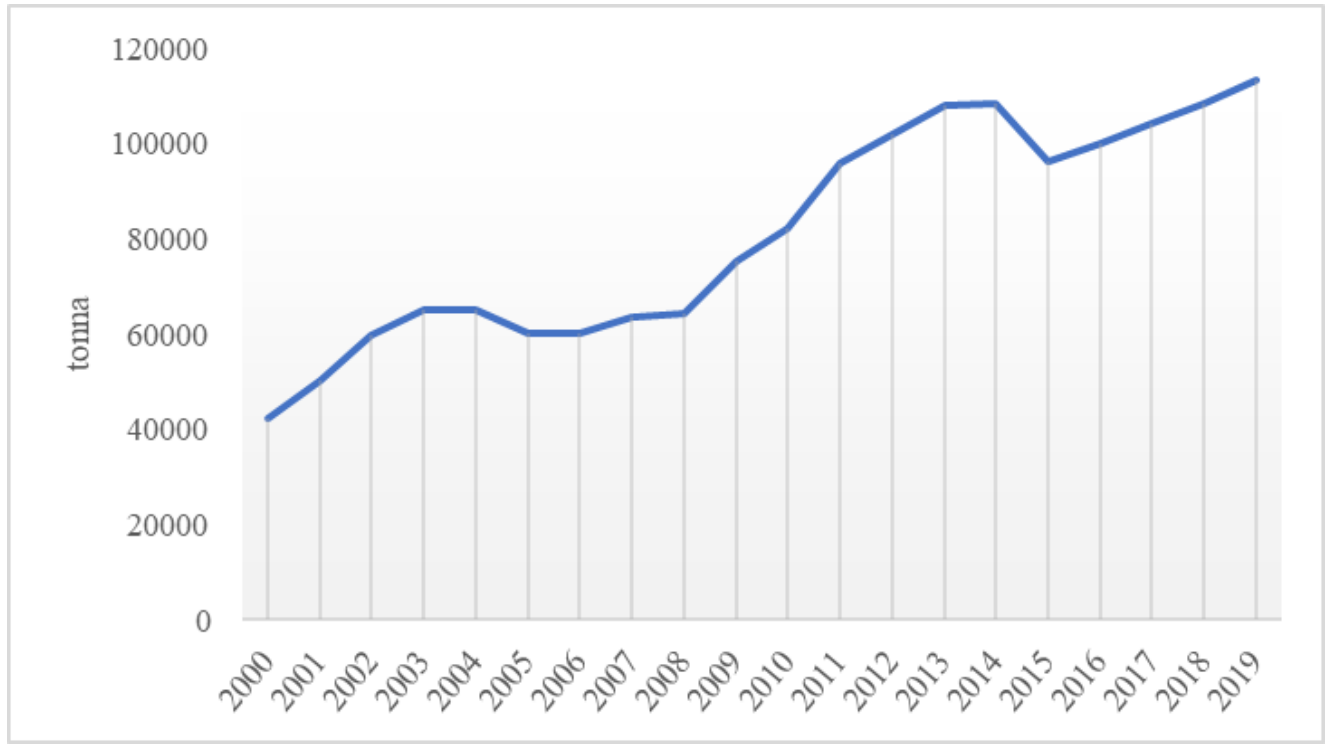

Forrás: FAO (2021a) adatai alapján a szerzők szerkesztése

2. ábra: A laoszi akvakultúra faji összetétele 2019-ben

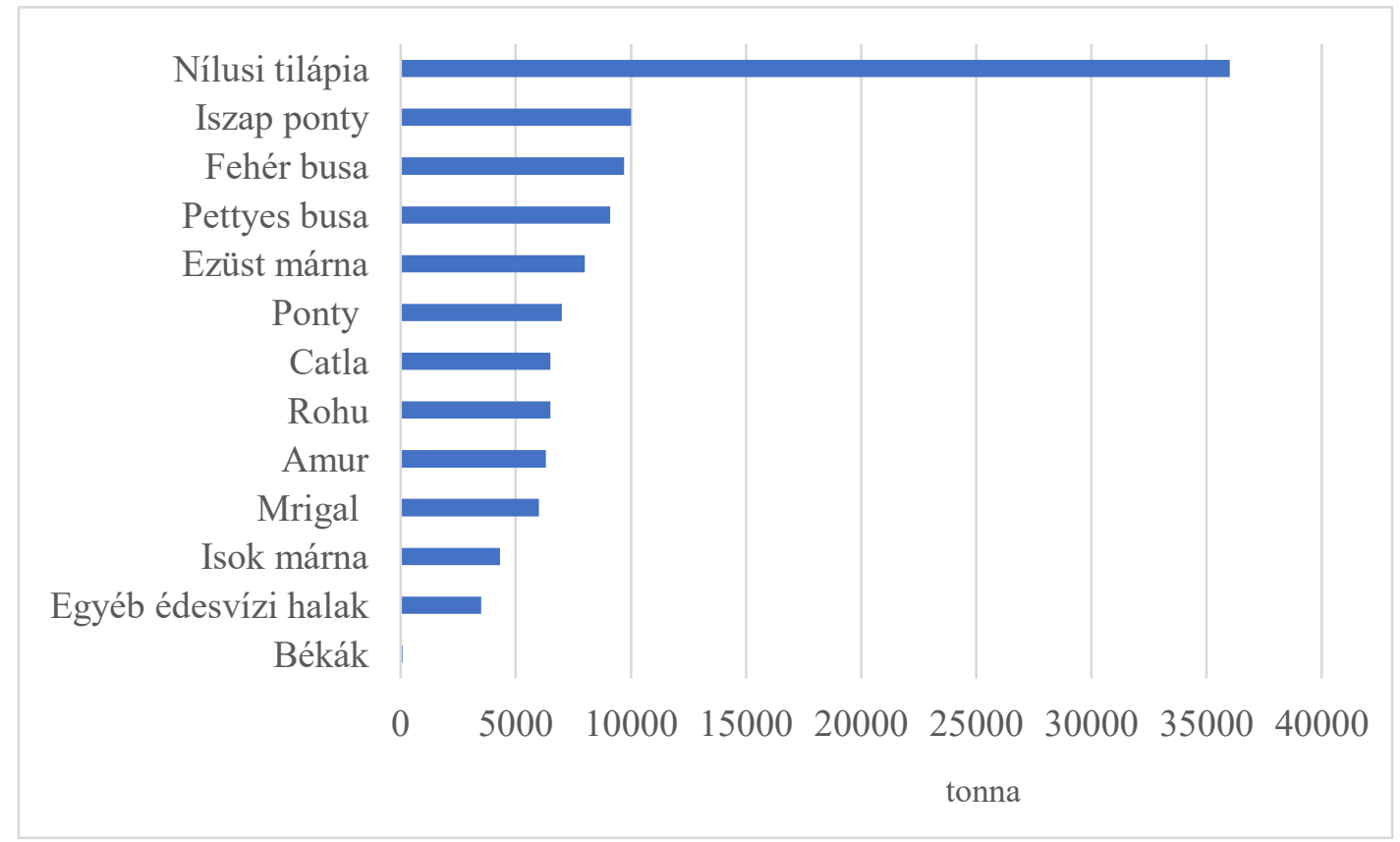

Forrás:FAO (2021a) adatai alapján a szerzők szerkesztése

Laoszban az akvakultúra szektorban jelenleg az alábbi három fö termelési technológia a meghatározó. 


\section{Ketreces haltermelés}

A ketreces haltermelésben a tilápia termelés a meghatározó, amely az utóbbi 20 évben fejlődött dinamikusan és mára a laoszi akvakultúra legjelentősebb ágazatává vált. A monoszex tilápia ivadék elsősorban Thaiföldről származik, amelyet sok esetben helyi farmokon kis tavakban nevelnek 5-10 cm-es méretüre. Az ivadékot ezután úszó ketrecekben import tápon nevelik piaci méretüre. Az átlagosan három hónapos tenyészidőszak alatt a tilápia eléri az 500 grammos méretet. Bár a technológiától és a menedzsment színvonalától függően a termelési adatok változnak, a megmaradás $80 \%$, illetve a takarmányértékesítési együttható $1,4 \mathrm{~kg}$ körüli. Az $1 \mathrm{~m}^{3}$-ben elérhető hozam elérheti a $30 \mathrm{~kg}$-ot. A ketreces tilápia termelés Vientiane tartományra koncentrálódik, ahol a folyókba és víztározókba telepített ketrecek száma az ezret is elérheti, bár sok a nem regisztrált farm is.

\section{Tavi haltermelés}

A tavi haltermelés a laoszi akvakultúra egy tradicionális, de ma is jelentős ágazta, amely sok vidéken élő lakos megélhetésének alapja. A tavi haltermelés fö halfajai a kínai növényevők, az indiai pontyok, a ponty, illetve a tilápia és az afrikai harcsa (Clarias gariepinus). A tógazdálkodás tehát alapvetően a nem öshonos fajok termelésén alapul, bár a tavi haltermelés kezdetén az ivadékot a környező vizekből fogták, illetve azok természetes úton kerültek be a tavakba. A tavi halnevelés során lehetőség van a különböző szerves hulladékok hasznosítására, így a termelési mód vonzó a szegény vidéki lakosság számára. A halastóterület az elmúlt 20 évben növekedett az útépítések, öntöző telep fejlesztések eredményeként, ahol a földnyerö helyeket szisztematikusan halastavakká alakították. A halastavi technológiákra a hagyományos módszerek és menedzsment alkalmazása jellemzö, így a tógazdálkodás fejlesztése a laoszi akvakultúra termelés nagy tartaléka. Így e területen van nagy lehetóség a tógazdaságokban alkalmazható új magyar technológiák alkalmazására.

Integrált haltermelés

Mint más ázsiai országokban, Laoszban is sajátságos eleme az akvakultúrának az integrált haltermelés (pl. állattartás-halnevelés; rizstermesztés-halnevelés) (Popp et al., 2018). Bár korábban az integrált haltermelés is elsősorban az őshonos fajok termelésén alapult, ma már e területen is meghatározóak az egzotikus fajok, elsősorban a kínai növényevők és a ponty. Az integrált haltermelési technológiák között kiemelt szerepe van a rizsföldi haltermelésnek, hiszen Laoszban meghatározó élelmiszertermelő ágazat a rizstermesztés. Ezen integráció is a rizsföldön felnövekedett vad halak befogásán alapult (6-40 kg/ha), azonban később szisztematikusan telepítettek halat a rizsföldekre, így hektáronként 300-600 kg halhozam is elérhető volt. A rizsföldi haltermelés fő halai az egzotikus ponty és tilápia, illetve az őshonos ezüst márna (Puntius gonionotus). Laoszban mintegy 200000 hektáron termelnek rizst, amelynek kb. 8-10\%-án alkalmazzák a rizs-hal integrációt (Phommavong, 2010). 


\subsection{Az akvakultúra fejlesztés lehetőségei, hal-értéklánc elemzés}

A fenntarthatóság, illetve fenntartható rendszerek és technológiák fejlesztése és üzemi alkalmazása az ázsiai akvakultúra fejlesztés alapvető kritériuma. A régió kutatóintézményei jelentős erőfeszítéseket tesznek az akvakultúra fenntarthatóságának növelése érdekében együttmüködve fejlett országok kutatóintézményeivel. Laoszban különösen kedvezőek a feltételek a rendszer és technológia fejlesztésre az akvakultúra területén, tekintettel a több évtizedes kapcsolatokra, az elmúlt években a gazdaságfejlesztés területén elért eredményekre. Laoszban kevés $\mathrm{K}+\mathrm{F}$ munka folyik a fenntartható akvakultúra rendszerek fejlesztésére irányulóan, pedig a környezeti-, gazdasági-, és társadalmi fenntarthatóság az akvakultúra fejlesztés területén is egyre fontosabb, hiszen a fenntarthatóság a versenyképesség növelésének alapvető eleme. A fenntarthatóság egyértelmü gazdasági kritériuma mellett Laoszban is egyre fontosabb a környezeti fenntarthatóság, a szigorodó környezetvédelmi kritériumoknak való megfelelés, illetve a társadalmi fenntarthatóság, amely magában foglalja a vidéken élők megélhetésének javítását, de a „környezet- és egészség tudatos” vásárlók igényeihez való igazodást is. A laoszi akvakultúra versenyképességének növelése különösen fontos, mivel Laosz is tagja az ASEAN Gazdasági Közösségnek, amelyen belül vámmentesen mozognak az élelmiszertermékek. Ez lehetőség, de egyben nagy kihívás is Laosz számára, ahol értékes "zöld" és humán erőforrások állnak rendelkezésre az élelmiszer termelésre, így a haltermelésre is, azonban egyelöre hiányoznak az erőforrás-hatékony és környezetbarát technológiák, fejletlen a feldolgozás, a csomagolás és a marketing, illetve jelenleg kidolgozás alatt van a hal értéklánc elemzés és a termékminősítési rendszer.

A laoszi akvakultúra fenntartható fejlesztéséhez mindenképpen szükséges a teljes értéklánc mentén történő szisztematikus elemzés, amely munka jelenleg folyamatban van. A laoszi hal értéklánc szerkezete a 3. ábrán látható.

\section{3. ábra: A laoszi hal értéklánc sematikus szerkezeti vázlata}

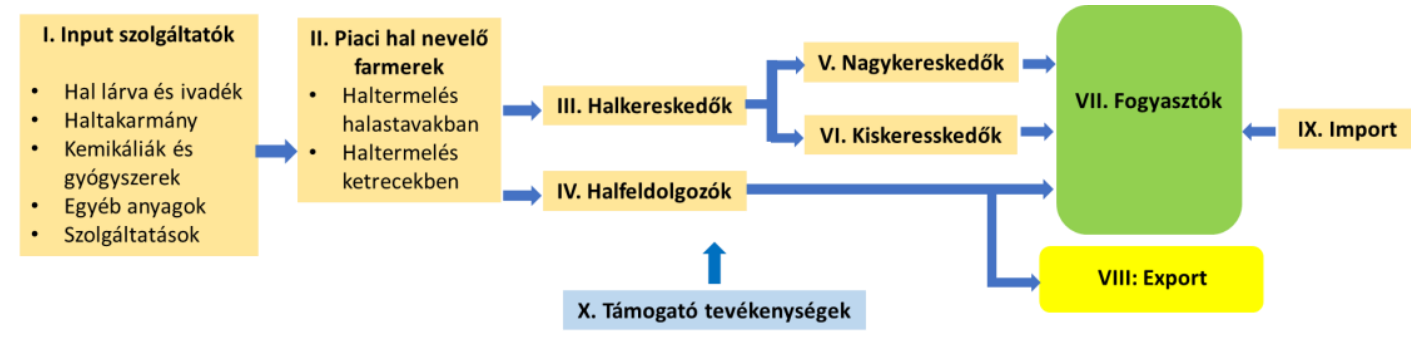

Forrás: Szerzők saját szerkesztése

Az értéklánc egyes elemire vonatkozó helyeztelemzés előzetes megállapításait röviden az alábbiakban foglaljuk össze.

\section{Input szolgáltatók}

A laoszi akvakultúra fejlesztés egyik legnagyobb problémája a jó minőségő ivadék hiánya. Az ivadékellátásban meghatározó állami halkeltetők müszaki állapota 
gyenge, hatékony müködtetésük feltételei korlátozottak. Az ivadék jelentős része sok esetben illegális importból származik és a behozott ivadékra jellemző a nem megfelelő minőség. Speciális haltakarmányok importból származnak (pl. CP, Betagro), bár a tilápia termelés felfutásával vannak példák helyi takarmánygyártásra is farm szintü és nagyobb üzemekben. Kemikáliák, gyógyszerek és egyéb a haltermelés során használt anyagok importból származnak, azonban ezek relatív kis mennyisége miatt ez az input nem olyan kritikus, mint az ivadék és a takarmány. A szolgáltatások (pl. elektromos energia, vízellátás, müszaki karbantartások) alacsony színvonalúak, de javuló tendenciát mutatnak.

\section{Piaci halnevelö farmerek}

A Laoszban hagyományos kis tavakban történő halnevelés tradicionális módszerekkel történik, azonban azok piaci alkalmazkodóképessége és külső negatív hatásokkal szembeni ellenálló képessége alacsony. Ugyancsak alacsony színvonalú a farmerek szervezettsége, így nincs együttmüködés egyrészt az input ellátás, másrészt az értékesítés területén. Az utóbbi évtizedben jelentősen megnövekedett a tilápia ketreces termelése, meghatározó módon kínai farmerek által. A laoszi farmerek új halfajok termelésével, egészséges és biztonságos hal elöállításával lehetnek versenyképesek a kínai termelőkkel szemben.

\section{Halkereskedök}

A laoszi hal ellátásban jellemző a halkereskedők (middleman) tevékenysége, akik a haltermelőktől felvásárolják a halat és azt a farmról el is szállítják. A legtöbb kisvállalkozó így kiszolgáltatott a halkereskedőknek.

\section{Halfeldolgozók}

Laoszban modern, korszerü technológiát alkalmazó üzemi halfeldolgozás nincs. Létezik azonban manufakturális halfeldolgozás, amely olyan hagyományos termékeket állít elö, mint például a szárított hal és a halszósz. Növekszik azonban az igény a korszerü és magas minőségủ feldolgozott haltermékek iránt, amit a növekvő import is jelez.

\section{Nagykereskedök}

A hal értékesítésben nem alakult ki olyan nagykereskedelmi tevékenység, mint például a baromfi és a sertés ágazatokban. Egyes nagyobb piacokon a piac menedzsment végez ilyen jellegü tevékenységet.

\section{Kiskereskedök}

A halértékesítés meghatározó módon hagyományos piacokon történik országszerte. Egyre kevesebb az utcai árus, viszont új tendencia, hogy egyes haltermelők saját üzletekben értékesítik termékeiket.

\section{Fogyasztók}

Laoszban a viszonylag magas halfogyasztás meghatározó módon a hagyományos haltermékek fogyasztását jelenti. Növekszik azonban az igény a feldolgozott és 
„kényelmi” termékek iránt, különösen a városi lakosok és a fiatalabbak körében. Ezen folyamatok azonban nem ismertek megfelelö mértékben.

\section{Export}

Laoszi halexport gyakorlatilag nem létezik, hosszabb távon azonban lehetőséget kínál egyes speciális, laoszi sajátosságokhoz köthető haltermékek exportja.

\section{Import}

A feldolgozott haltermékek importja növekvő tendenciát mutat, elsősorban magasan feldolgozott (pl. konzerv) termékekből. Megjegyezzük, hogy Thaiföld, amelyik a világ egyik jelentős halexportőre Laosz szomszédja, illetve a két ország között igen aktív a kereskedelmi kapcsolat.

\section{$X$. Támogató tevékenységek}

A támogató tevékenységek, közöttük a szakirányítás a szabályozó és támogató rendszerekkel, továbbá a $\mathrm{K}+\mathrm{F}$ és az oktatás színvonala még messze elmarad a nemzetközi szinttől, bár folyamatos a fejlödés e területen.

A laoszi hal értéklánc felmérésnek eredményeit, illetve korábbi tapasztalatokat figyelembe véve a hal értéklánc fejlesztésére irányulóan a magyar kötött segélyhitelprogram keretében az alábbi specifikus programok megvalósítása van folyamatban:

- Halivadék ellátás fejlesztése (tartományi halkeltetők, ADC, LARReC, NAFDEC);

- Haltakarmány ellátás (speciális halivadékgyártó gépsor Nongtengben);

- Jó Tógazdasági Gyakorlat bevezetése modell farmokon Namxouang tartományban;

- Modern halfeldolgozó létesítése és termékfejlesztés;

- Haltermék minősítési rendszer kidolgozása

(„Minőségi Laoszi-Magyar Hal”);

- Fogyasztói felmérések különböző vásárlói szegmensekben;

- Halértékesítési pontok kialakítása;

- Halpromóciós programok szervezése.

\section{Magyar részvétel a laoszi akvakultúra fejlesztésben}

\subsection{Előzmények, szakmai alapok és eredmények}

Bár Magyarország haltermelése nem számottevő még európai mércével mérve sem, a magyar édesvízi akvakultúra $\mathrm{K}+\mathrm{F}$ és innovációs eredményei világviszonylatban is elismertek különösen a pontytenyésztés és fenntartható édesvízi haltermelési technológiák és termelési rendszerek fejlesztése területén. Hazánk, különösen a Halászati és Akvakultúra Kutatóintézet (HAKI) révén évtizedek óta aktív résztvevője fejlődő országok akvakultúra fejlesztésére irányuló projekteknek elsősorban szakértői munkával, és szakmai továbbképzéssel. Az ENSZ és a FAO által kezdeményezett, az éhség és a szegénység felszámolására irányuló programok keretében végzett munka kezdetben elsősorban FAO projektek keretében folyt, de 
kapcsolódott az kínai, indonéz, laoszi, thaiföldi és vietnami halászati kutatóintézettekkel kialakított kétoldalú $\mathrm{K}+\mathrm{F}$ együttmüködésekhez is. Amikor Magyarország 2004-ben EU-tagországgá vált új lehetősségek nyíltak a fejlődő országok élelmiszergazdaságának fejlesztésében donorként való részvételre. Ilyenek voltak például a NEFE (Nemzetközi Fejlesztési Együttmüködés) programok, majd később a kötött segélyhitel programok, amelyekben fontos szerepet játszott a halászat- és akvakultúra fejlesztés különös tekintettel az ázsiai régióra, ahol Laosz Magyarország tradicionális partnere.

A magyar jelenlét a laoszi akvakultúra fejlesztésben mintegy 40 évre tekint vissza, amikor magyar szakértők FAO projektek keretében dolgoztak Laoszban a halivadékellátás javítása érdekében. A kapcsolatok megalapozták későbbi $\mathrm{K}+\mathrm{F}$ együttműködések kialakítását, amelyek elsősorban a pontytenyésztésre és halastavi technológiák fejlesztésére irányultak. E munka elsősorban a HAKI és a laoszi Élő Vízi Erőforrások Kutatási Központja (LARReC) közötti együttműködés keretében folyt és közös kutatómunkát, illetve laoszi szakemberek magyarországi képzését foglalta magában. A szakmai együttműködés a magyar szakértők laoszi munkáját, illetve laoszi szakemberek képzését, majd $\mathrm{K}+\mathrm{F}$ együttmüködést követően szervesen fejlődött a gazdasági együttműködés irányába, amelynek a kibontakozását a magyar kötött segélyhitel programok tették lehetővé. Megjegyzendő, hogy ilyen programok végrehajtásának feltételeit Magyarországon is meg kellett teremteni. Erre jó alapot szolgáltatott a dabasi Vitafort Zrt. innovációs tevékenysége és hazai kutatóintézetekkel, közöttük a HAKI-val való együttmüködése. Így a Vitafort Zrt., illetve az általa létrehozott Vitafort Agro Ázsia Zrt. lett a laoszi fél által is elfogadott fővállalkozója az agrár kötött segélyhitel programoknak.

Az első magyar kötött segélyhitel program végrehajtására 2009 és 2011 között került sor. Ez a program elsősorban infrastruktúra fejlesztést foglalt magában, amely a minőségi tenyészanyag és takarmány ellátás fejlesztését szolgálta. A fejlesztés keretében három korszerü takarmánygyártó üzem, egy modern vágóhíd és húsfeldolgozó üzem, valamint egy halivadéknevelő gazdaság épült.

A 2016-ban kezdődő és 2018-ban befejeződött 2. kötött segélyhitel program kiemelten a laoszi élelmiszerláncbiztonsági rendszer fejlesztésére irányult, fontos eleme volt azonban olyan modell gazdaságoknak a létrehozása és müködtetése, amelyek demonstrálták a minőségi élelmiszer elöállítás teljes folyamatát a termőhelytől a piacig. A modell gazdaságok között példaértékü az Akvakultúra Fejlesztési Vállalat (Aquaculture Development Company, ADC), amelyik magyarlaoszi vegyes vállalatként müködik a magyar Aranyponty Zrt. és a laoszi Sahamit cég együttmüködésében.

A harmadik kötött segélyhitel program 2019-ben kezdödött és 2022 végén fejeződik be. A programnak nyolc komponense van a következők szerint: (1) talajgazdálkodás; (2) növénytermesztés; (3) vízgazdálkodás; (4) szarvasmarha tenyésztés; (5) halászat és akvakultúra; (6) „post-harvest” technológiák; (7) élelmiszerlánc biztonság; és (8) humán erőforrások fejlesztése. A halászati komponens az e területen végzett korábbi munkák és új fejlesztések eredményeire alapozva a teljes hal értéklánc fejlesztésére irányul, így magában foglalja az 
anyahaltartást, a szaporítást és az ivadékellátást, a piaci hal termelést, a haltakarmány ellátást, a halfeldolgozást és az értékesítést. A jelenlegi program keretén belül az akvakultúra fejlesztési komponens részaránya 3 millió USD, ami a teljes költségvetés kb. $9 \%$-a. A projekt kiemelt figyelmet fordít a minőségi halivadék és haltakarmány ellátásra. E munka magában foglalja kiválasztott tartományi halkeltetők és halivadékellátó központok fejlesztését, illetve magán haltermelő gazdaságok támogatását, kisebb részben berendezésekkel és eszközökkel, nagyobb részben tudással és technológiával. A hal értéklánc végén megjelenik a projekt keretében kidolgozott „Laoszi-Magyar Minőségi Hal” kritérium rendszer alapján minősített, feldolgozott és csomagolt egészséges és biztonságos haltermék. Új haltermék megjelenése a modern halfeldolgozó felépítését és üzembe helyezését követően 2022 év végén várható.

A halászati és akvakultúra fejlesztési program alapvetően $\mathrm{K}+\mathrm{F}$ eredmények gyakorlati alkalmazását, a laoszi körülményekre adaptálását tartalmazza a teljes hal értéklánc mentén. Fontos szempont ugyanakkor, hogy a program végrehajtásánál figyelembe vegyük a laoszi gazdasági és társadalmi sajátosságokat. Ezek közül kiemelhető egyrészről a feldolgozott import haltermékek vásárlását preferáló fogyasztók bizalmának megnyerése, másrészről a termelők és feldolgozók vállalkozási kultúrájának és technológiai fegyelmének javítása. Természetesen ezeknek a komoly kihívást jelentő feladatoknak a végrehajtása csak modell keretekben történhet, amelyek szélesebb körü alkalmazása, illetve annak elősegítése újabb és hosszabb távú programok keretében történhet. Jó alapja a további fejlesztéseknek az említett magyar-laoszi vegyesvállalat müködése, amelyik minőségi halivadékot termel, amely iránt a kereslet egyre növekszik, továbbá az eddigi munka során létrehozott partnerkapcsolatok állami intézmények és magánvállalkozások között (Public Private Partnership).

\subsection{Jövőbeni lehetőségek}

A magyar kötött segélyhitel programok korábban soha nem látott lendületet adtak a laoszi akvakultúra fejlesztésnek, alapvető fontosságú azonban ennek a lendületnek a megtartása, illetve a program eredményei fenntarthatóságának a biztosítása. Reális veszély, hogy a program lezárását követően, amikor már nem lesz állandó magyar szakember jelenlét Laoszban elvész a projekt által adott lendület.

Segíthet azonban a fejlesztési program továbbvitelén és az eredmények alkalmazásában és szélesebb körü elterjesztésében a halivadéknevelö magyar-laoszi vegyesvállalat müködése, amely modellként szolgál és szakmai támogatást is nyújthat nem csak az ivadéknevelés, de a hal értéklánc más elemeire vonatkozóan is. Segíthetik továbbá a magyar-laoszi halászati és akvakultúra együttmüködés hosszú távú fejlesztését a hagyományos, de a kötött segélyhitel programok által megerősített $\mathrm{K}+\mathrm{F}$, illetve oktatási partnerkapcsolatok, továbbá az újonnan létesített együttműködés a Magyar Agrár- és Élettudományi Egyetem (MATE) és a Laoszi Nemzeti Egyetem (NUoL) között. Hasznos lenne továbbá a kötött segélyhitel programok folytatása egy olyan kisebb költségvetésủ program keretében, amelyik a megvalósult három program eredményeinek fenntarthatóságát hivatott elősegíteni. 
Ahogy említettük, Magyarország laoszi jelenléte erősíti a regionális együttmüködéseket a Délkelet-ázsiai akvakultúra fejlesztés területén. A laoszi kötött segélyhitelek végrehajtása során például négyoldalú együttműködést írt alá a HAKI, a vietnami partnere, az 1.sz. Akvakultúra Kutatóintézet (RIA-1), a Vitafort Agro Ázsia Zrt. és a vietnami Mavin cég. Az együttmüködés a minőségi pontyivadék ellátásra és a minőségi takarmányellátásra irányul. Sajnos a Covid járvány az információcserére korlátozta az együttmüködést, de a helyzet konszolidálását követően beindulhat a tervezett közös munkaprogram. A laoszi kötött segélyhitel program elősegítette a HAKI és a thaiföldi Mezőgazdasági és Szövetkezeti Minisztérium Halászati Főosztálya közötti együttmúködési megállapodás létrehozását, illetve thaiföldi szakembereknek bevonását a laoszi akvakultúra alapú halászati programkomponensbe. Erősödtek a magyar-kínai kapcsolatok is az akvakultúra fejlesztés területén, miután a HAKI kínai együttmúködő partnere az Édesvízi Halászati Kutató Központ (FFRC) Laoszban is jelen van. Magyarország agrárpolitikájának egyik fontos eleme az exportbővítés, amelyhez a Laoszban végrehajtott kötött segélyhitel programok keretében létrehozott rendszerek és kapcsolatok jó alapot szolgáltatnak a Délkelet-ázsiai régióban.

\section{Következtetések}

A világ növekvő népességének egészséges élelmiszerrel történő ellátásában az akvakultúrának kiemelt szerepe lehet a jövőben tekintettel a vízi erőforrások fenntartható hasznosításában rejlő lehetőségekre. A világ akvakultúra termelésében meghatározó édesvízi akvakultúra fejlesztése a világ szegényebb régióiban továbbra is fontos feladat lesz. Ilyen programokban hazánk eredményesen vehet részt miután az édesvízi akvakultúrában, különösen a tógazdálkodás területén hazánk nemzetközileg is elismert eredményekkel és tapasztalatokkal rendelkezik. A magyar segítséggel folyó laoszi akvakultúra fejlesztési program jó példája annak, hogy a hagyományos szakmai kapcsolatokra épülö célirányos és kölcsönös érdekeltségen alapuló támogatási konstrukció, nevezetesen a kötött segélyhitel felhasználása hatékonyan segítheti egy szegény ország élelmiszerellátásának fejlesztését.

Egy célirányos kötött segélyhitel program beindításához természetesen szükség van a donor és a kedvezményezett ország közötti rendezett kapcsolatra, ami Magyarország és Laosz között adott, hiszen a két ország 60 évvel ezelőtt létesített diplomáciai kapcsolatot és 2019-ben a két ország miniszterelnökei stratégiai megállapodást írtak alá. A laoszi kötött segélyhitel programok végrehajtása során hatékonynak bizonyult a farmerekkel, illetve modell farmokkal együttmüködésben végzett munka az állami szféra és magánvállalkozások közötti partner kapcsolat (Public Private Partnersip, PPP) keretében. Ez a partnerkapcsolat egyaránt fontos a donor- és a kedvezményezett ország részéröl. Magyar részről jó alapadottság volt az, hogy a projekt fővállalkozójának a Vitafort Agro Ázsia Zrt.-nek az anyavállalata a Vitafort Zrt. partnerkapcsolatban áll hazai kutatóintézetekkel, közöttük a HAKI-val. Laoszi oldalon ugyanakkor külön erőfeszítést igényelt a PPP kialakítása. A laoszi akvakultúra fejlesztési program - amely eredményeképpen egy magyar-laoszi halivadéknevelő vegyesvállalat is létrejött - jó példája annak hogyan hasznosíthatók 
a korábbi szakmai kapcsolatok és $\mathrm{K}+\mathrm{F}$ eredmények sikeres gazdasági együttmüködés kialakításához.

A laoszi akvakultúra fejlesztési program eredményei és tapasztalatai tovább erősítették a magyar jelenlétet a dinamikusan fejlődő Délkelet-ázsiai régióban, ahol további lehetőségek kínálkoznak édesvízi akvakultúra fejlesztési programokban történő részvételre. A magyar részvétel a szakértöi munkán és a szakmai továbbképzésen túl megalapozhat gazdasági együttmüködéseket is az akvakultúra területén túlmutatóan, mint történt ez Laoszban is. Továbbra is fontos a kormányzati szervek, az állami intézmények és a magánvállalkozások együttmüködése, illetve az eddigi kedvező eredmények és tapasztalatok hasznosítása új projektek adta lehetőségek kihasználása érdekében.

\section{Irodalomjegyzék:}

FAO (2020): The State of World Fisheries and Aquaculture (SOFIA). Series number: 2020 - SOFIA 2020. Publisher: FAO. <https://www.fao.org> ISBN: 978-92-5-132692-3.

FAO (2021a): Fishery and Aquaculture Statistics. Global aquaculture production 1950-2019 (FishstatJ). In: FAO Fisheries and Aquaculture Department, Rome. Updated 2021. $<$ www.fao.org/fishery/statistics/software/fishstatj/en>

FAO (2021b): AQUASTAT Database. AQUASTAT Website. (2021. 11. 30.)

GCA (2020, 2021): Global Conference on Aquaculture (GCA), 2020. Shanghai Declaration. $<$ https://aquaculture2020.org/declaration/>

KSH (2021): Fenntartható Fejlödési Célok. <https://www.ksh.hu/sdg>

McCartney M., Brunner J. (2020): Improved water management is central to solving the waterenergy-food trilemma in Lao PDR. International Journal of Water Resources Development, https://doi.org/10.1080/07900627.2020.1754175

Naylor, R. L., Kishore, A., Sumaila, U. R. et al. (2021): Blue food demand across geographic and temporal scales. Nature Communications, 12,5413. https://doi.org/10.1038/s41467-021-255164

Phommavong, T. (2010): Country Report Of Aquaculture Production In Lao PDR. ASEAN training course on Aquaculture Production. <http://www.slideshare.net/ridzaludin/country-report-ofaquaculture-production-in-lao-pdr>

Popp J., Váradi L., Békefi E., Péteri A., Gyalog G., Lakner Z., Oláh J. (2018): Evolution of Integrated Open Aquaculture Systems in Hungary: Results from a Case Study. Sustainability, 10 (1): 177. https://doi.org/10.3390/su10010177

The United Nations (2020): PROGRESS REPORT in Lao PDR- United Nations Partnership Framework 2017-2021.33 pp.

$<$ https://laopdr.un.org/sites/default/files/2021-07/Progress\%20Report\%202020.pdf>

Waite, R., Beveridge, M., Brummett, R., Castine, S., Chaiyawannakarn, N., Kaushik, S., Mungkung, R. Nawapakpilai, S., Phillips, M. (2014): Improving Productivity and Environmental Performance of Aquaculture. Working Paper, Instalment 5 of "Creating a Sustainable Food Future". Washington, DC, World Resources Institute. 59 pp. 